\title{
Natural Preservation of Woods using Sambiloto (Andrographis paniculata) Leaf Extract for Making Wooden Batik Crafts
}

\author{
Istihanah Nurul Eskani*, I Made Arya Utamaningrat \\ Center for Crafts and Batik, Jl. Kusumanegara No. 7 Yogyakarta 55166 \\ *E-mail: hana.eskani@gmail.com
}

DOI: https://doi.org/10.26874/jkk.v2i2.35

Received: 14 Oct 2019, Revised: 30 Oct 2019, Accepted: 31 Oct 2019, Online: 30 Nov 2019

\begin{abstract}
Indonesia is one of wood craft producer. Indonesian crafts have been exported to many countries, such as Japan, Europe and America. Commonly, that crafts used chemical preservatives that identified not safe for environment. A lot of countries had banned the use of toxic preservatives such as arsenic and chromium-based preservatives. Therefore, it is important to use natural preservatives that are safer for human being and the environment. This research aimed to know the ability of Sambiloto (Andrographis paniculata) leaf extract to use as wood preservatives and to determine the preservative treatability of two woods, Mahoni (Swietenia mahogany) and Matoa (Pometia pinnata) woods as material for making interior products such as wooden batik crafts. Matoa and Mahoni wood were preserved by hot bath at temperature of $\pm 80 \mathrm{oC}$ using Sambiloto leaf extract with variation of concentration of $10 \%, 12.5 \%$ and $16.67 \%$ for immersion time of 1 hour, 2 hours and 3 hours. The retention value of each variation was calculated and compared with the preservative value for the interior product of SNI 03.5010-1.1999 ( $\geq$ $8 \mathrm{~kg} / \mathrm{m} 3$ ). The results show that preservation of Matoa wood for indoor uses can be done using Sambiloto leaf extract with concentration of $12.5 \%$ and processing time of 2 hours. However, the retention values for Mahoni woods were lower than SNI for all treatment because of its extractive content that make it hard to be preserved.
\end{abstract}

Keywords: batik, wooden crafts, natural preservation, sambiloto

\section{Introduction}

Wood is a renewable resource that is not only easy to get and available all around the world but also has an attractive natural appearance. Those are the reason of its increased use in our daily live [1]. Indonesia has more than 4000 kind of woods with around $80 \%-85 \%$ of it included in low durability class (III, IV,V) that needs to be treated beforehand to prolong its lifetime [2]. Nowadays, wood supplies from natural forest have been decreasing because of the damages it suffers. This condition resulted in uses of wood from industrial plants woods. In general, these woods are young, small in diameter $(<25 \mathrm{~cm})$, and have low quality. Technology that is able to process and better the properties of these wood such as sawing pattern, drying, preservation, etc. are required [3].

Wood that is suitable for making craft has an attractive pattern (decorative), smooth texture, durable (Durability Class II is preferred), moderate strength and hardness (density of 0.550.75 ) and stable [4]. Because of the decline of the forest, the wood craftsmen are not too concerned with the above requirements, so that it is widely used the woods that have low durability. Therefore, proper preservation is needed, including simple and inexpensive preservatives, toxic to wood-damaging organisms, especially dry wood termites that usually damage handicrafts [5].

Wood preservation is a process of penetration of chemical substances or preservatives to prolong its lifetime [6]. Wood treatability is wood ability to be penetrated by a preservatives that is economically beneficial and effective to prevent wood-damaging factors [1]. According to Barly and Martawijaya [7], wood treatability is affected by 4 main factors, which are type of wood (anatomical structure, extractive substances, 
density), the condition of wood before preservation (water content, shape of the wood), preservation method (hot/cold, pressurized preservation), and the preservative used. Dumanau in Kurnia [6] stated that wood preservatives, such as arsenic (As), copper $(\mathrm{Cu})$, Flour $(\mathrm{F})$, chrome $(\mathrm{Cr})$, Zinc $(\mathrm{Zn})$ was highly toxic to wood-damaging pest. In the last few years, a lot of country has banned the uses of arsenic and chromium-based preservatives. For example, the Environmental Protection Agency who have banned the uses of Chromated Copper Arsenat (CCA) as preservative for building wood [8]. Because of that reason, it was necessary to find an alternative preservative that is save for living beings and environment. In this research, sambiloto leaf (Andrographis paniculata) was extracted and used in preservation of woods commonly used as material for craftmaking, i.e Matoa wood (Pometia pinnata) and Mahoni wood (Swietenia mahogany). Sambiloto leaf contains saponin, flavonoid, alkaloid and tannin [9]. Saponin can be used as preservative since it is an anti-microbes that is able to damage cytoplasm membrane and kill cells [10].

Matoa Wood (Pometia pinnata) is largely found in Papua and has long been used as construction and furniture materials. Matoa wood has a density of $0.56-0.99$, strength class of II-III and durability class of III in which it has to be treated before uses. Mahoni wood (Swietenia mahogany) has a density of $0.53-0.72$, strength class of II-III and durability class of III, it is widely used for building, plywood, furniture, and handicraft. Some reason of why mahoni wood is widely used are its beautiful colour and fibre pattern, strength and easy to work with [11]. This research aimed to see the preservative treatability of matoa and mahoni wood by using sambiloto leaf preservatives. Treatability of these woods was determined by its retention value. Retention is the amount of preservatives that penetrates and remain inside the wood and measured in $\mathrm{kg} / \mathrm{m}^{3}$ [12]. SNI standard 03.5010-1.1999 requires a retention value of $8 \mathrm{~kg} / \mathrm{m}^{3}$ for indoor uses and 11 $\mathrm{kg} / \mathrm{m}^{3}$ for outdoor uses [6]. So for wooden batik crafts that commonly used for decorative indoor, the reference value for retention is $8 \mathrm{~kg} / \mathrm{m}^{3}$.

\section{Material and Method}

\subsection{Material}

Materials used in this research were: matoa wood from Kulon Progo Yogyakarta, mahoni wood from Bantul Yogyakarta, sambiloto leaf from local market Beringharjo Yogyakarta, water.
Equipments used in this research were: thermometer (alcohol based), boiling pan, stove, moisture meter, saw, digital balance, laboratory glassware.

\subsection{Method}

Mahoni and Matoa woods were cut by $15 \mathrm{~cm}$ x $6 \mathrm{~cm} \mathrm{x} 4 \mathrm{~cm}$ and naturally dried in a room temperature for 30 days until it has around $15 \%$ water content. Its water content and wood mass were then measured before preservation. Preservative solution was made by extracting sambiloto leafs using water solvent. The mixture of Sambiloto leaf and water was boiled at $80{ }^{\circ} \mathrm{C}$ for \pm 3 hours to produce natural preservatives with a concentration of $10 \% \mathrm{wt}, 12.5 \% \mathrm{wt}$ and $16.67 \%$ wt. Mahoni and Matoa woods were then immersed on the boiling pans containing preservative of each concentration. It was heated and held at $\pm 80^{\circ} \mathrm{C}$ for 1,2 , and 3 hours. Each experiment was repeated for 3 times to ensure its validity. As the immersion duration completed, the specimen was drained and had its water content measured. It was also weighed for retention measurement. Retention value can be determined using equation (1).

$R=\frac{B_{1}-B_{0}}{V} x K$

$$
\begin{array}{ll}
\mathrm{R} & \text { : retention value of preservatives }\left(\mathrm{kg} / \mathrm{m}^{3}\right) \\
\mathrm{B}_{1} & \text { : specimen mass after preservation }(\mathrm{kg}) \\
\mathrm{B}_{0} & : \text { specimen mass before preservation }(\mathrm{kg}) \\
\mathrm{V} & : \text { speciment volume }\left(\mathrm{m}^{3}\right) \\
\mathrm{K} & \text { : preservatives concentration }
\end{array}
$$

\section{Results and Discussion}

Drying of matoa and mahoni wood (around $15 \%$ water content) before preservation has been carried out to make it easier for the preservatives to penetrate the wood. Saturated water content in wood (around 30\%) would be hard to be penetrated by the preservatives. Retention values of sambiloto extract on matoa wood can be seen on Figure 1. 


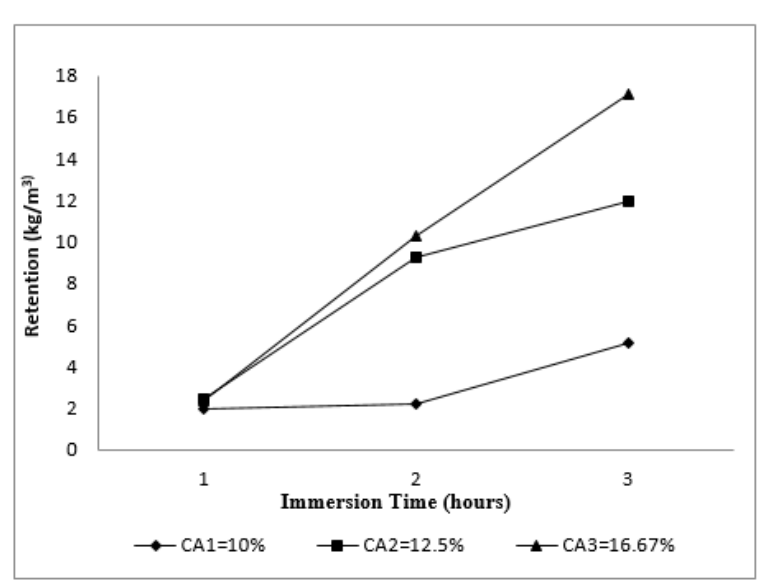

Figure 1. Retention Value of Sambiloto Extract Preservatives on Matoa Wood

Figure 1 shows that the duration of preservation and the concentration of the preservatives positively affecting the retention value, which means retention value will increase along the increase in immersion duration and preservatives concentration. This result is consistent with Mariana's research [13] which preserved durian wood (Durio zibethinus) using kumis kucing leaf (Orthosiphon aristatus) preservatives. Barly dan Lelana [8] had also a similar result in preserving sengon wood (Paraseriantheus falcataria) and tusam (Pinus merkusii) using boric acid (BAE). The lowest retention value of matoa preservation in this research is $2 \mathrm{~kg} / \mathrm{m}^{3}$ on $10 \%$ preservatives concentration and 1 hour of immersion, while the highest retention value is $17.1 \mathrm{~kg} / \mathrm{m}^{3}$ on $16.67 \%$ concentration and 3 hours of immersion. When compared to SNI 03.5010-1.1999, matoa wood preserved with preservatives concentration of $12.5 \%$ and 2 hours of immersion could be used for indoor application since it resulting in $9.3 \mathrm{~kg} / \mathrm{m}^{3}$ retention value that is above the standard of 8 $\mathrm{kg} / \mathrm{m}^{3}$.

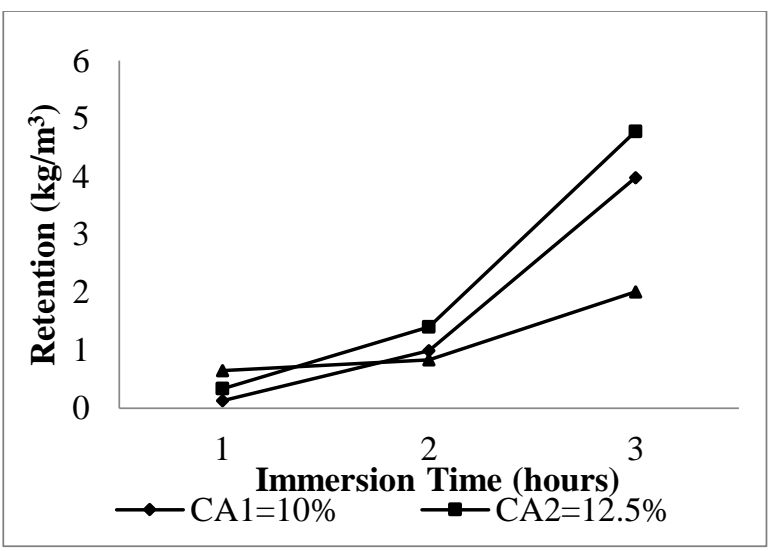

Figure 2. Retention Value of Sambiloto Extract Preservatives on Mahoni Wood.

Retention value of mahoni wood is shown in Figure 2. In general, the longer the immersion duration, the higher the retention value will be. The highest retention value for mahoni wood is $4.8 \mathrm{~kg} / \mathrm{m}^{3}$ on $12.5 \%$ preservatives concentration and 3 hours of immersion, while the lowest value is $0.1 \mathrm{~kg} / \mathrm{m}^{3}$ on $10 \%$ preservatives concentration and 1 hour of immersion. For $16.67 \%$ preservatives concentration, the value was too small so the optimum preservatives concentration for mahoni wood preservation in this research was obtained at preservative concentration of $12.5 \%$ wt. When compared to SNI 03.50101.1999 , there are no mahoni wood's retention value reach the standard. According to Barly and Martawijaya [7], treatability of wood is affected by its properties such as density, anatomical structure and its extractive substances. Naelufar [14] stated that mahoni wood has a high content of extractive substance (5.13\%) which causes preservatives difficult to penetrates the wood. This result is also consistent with Djauhari and Rahayu's research [12] that stated mahoni wood is hard to be preserved. Figure 3 shows a comparison of retention values between matoa and mahoni woods. In all treatments, matoa wood has a higher retention values when compared to mahoni wood.

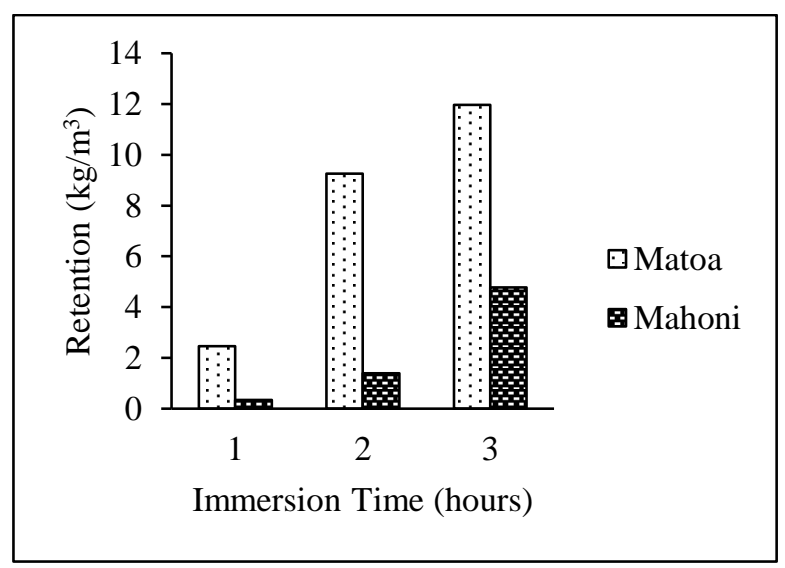

Figure 3. Comparison of Retention Value between Matoa Woods and Mahoni Woods at Preservatives Concentration of $12.5 \% \mathrm{wt}$

\section{Conclusion}

Matoa wood can be preserved using the extract of sambiloto leaf. For making wooden batik crafts that commonly used for decorative indoor, matoa wood can be preserved using sambiloto extract with a concentration of $12.5 \%$ for 2 hours (retention value is $9.3 \mathrm{~kg} / \mathrm{m} 3$ ). 
Preservation of mahoni wood using sambiloto extract results in below standard retention values (SNI 03.5010-1.1999). Value of retention is affected by extractive substances inside of the wood. In this case, mahoni turns out to have high number of extractive substances that hinder preservatives to penetrate the wood.

\section{Acknowledgements}

This research was supported by DIPA Balai Besar Kerajinan dan Batik, Yogyakarta. We thank to our colleague Mr. Dwi Suheryanto who provided insight and expertise that greatly assisted this research.

\section{References}

[1] Batubara R. Teknologi Pengawetan Kayu Perumahan Dan Gedung Dalam Upaya Pengawetan Hutan. Medan (2006).

[2] Jasni J. Keawetan 57 Jenis Kayu Indonesia Alami Dengan Pengujian Di Bawah Naungan . J Penelit Has Hutan 34(3):179188

(2016). doi:10.20886/jphh.2016.34.3.179-188

[3] Abdurachman, Hadjib N. Pemanfaatan kayu hutan rakyat untuk komponen bangunan. m:130-148 (2006)

[4] Wahyudi I. Hubungan Struktur Anatomi Kayu dengan Sifat Kayu, Kegunaan dan Pengolahannya (2013), http://www.fordamof.org/files/Imam_Wahyudi-IPB.pdf.

[5] Abdurrohim S. Pengawetan Tiga Jenis Kayu untuk Barang Kerajinan memakai Dua Jenis Bahan Pengawet Bor secara Rendaman Dingin. J Penelit Has Hutan, 10(2):54-58. (1992)

[6] Kurnia A. Sifat Keterawetan dan Keawetan
Kayu Durian, Limus dan Duku Terhadap Rayap kayu Kering, Rayap Tanah dan jamur Pelapuk (2009)

[7] Barly, Martawijaya A. Keterawetan 95 Jenis Kayu terhadap Impregnasi dengan Bahna Pengawet CCA. Bul Penelit Has Hutan, 18(2):69-78 (2000)

[8] Barly, Lelana NE. Pengaruh Ketebalan Kayu, Konsentrasi LArutan dan Lama Perendaman terhadap Hasil Pengawetan Kayu. Penelit Has Hutan., 28(1):1-8 (2010)

[9] Dalimunthe A. Interaksi Sambiloto (Andrographis Paniculata). Medan, (2009)

[10] Pusung WA, Hengky P, Tandi S. Uji Efektivitas Ekstrak Daun Sambiloto (A Paniculata Nees) sebagai Bahan Pengawet Alami Tomat dan Cabai Merah. Akad Kim., 5(August):146-152 (2016)

[11] Mindawati N, Megawati. Manual Budidaya Mahoni (Swietenia Macrophylla King). Jakarta: Badan Penelitian dan Pengembangan Kehutanan-Kementerian Kehutanan (2013)

[12] Djauhari D, Rahayu IS. Pengaruh Konsentrasi Bahan Pengawet Boron terhadap Retensi dan Penetrasi pada Kayu Rakyat (2012)

[13] Mariana E, Ariyanti, Erniwati. Uji Retensi dan Efektivitas Tanaman Kumis Kucing (Orthosiphon aristatus) Terhadap Serangan Rayap Tanah(Coptotermes sp) Pada Kayu Durian (Durio zibethinus). War Rimba.,1(1), (2013)

[14] Naelufar A. Zat Ekstraktif Kayu Mahoni ( Swietenia macrophylla King) dan Pengaruhnya terhadap Nilai Kalor (2014) 